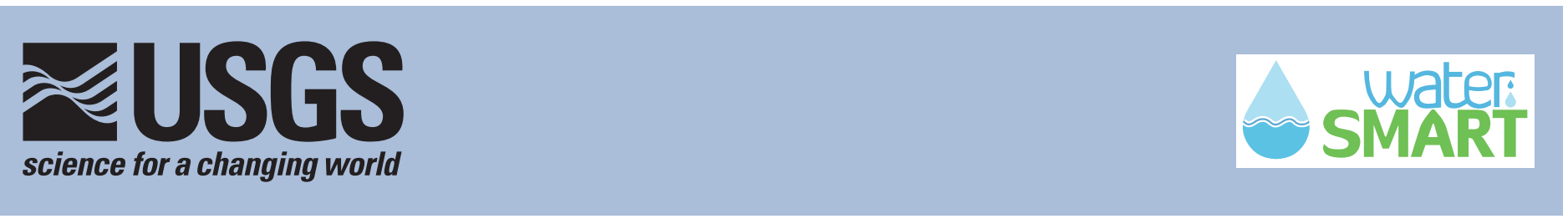

\title{
Dissolved Methane in Groundwater, Upper Delaware River Basin, Pennsylvania and New York, 2007-12
}

○

\section{Introduction}

The prospect of natural gas development from the Marcellus and Utica Shales has raised concerns about freshwater aquifers being vulnerable to contamination. Well owners are asking questions about subsurface methane, such as, "Does my well water have methane and is it safe to drink the water?" and "Is my well system at risk of an explosion hazard associated with a combustible gas like methane in groundwater?"

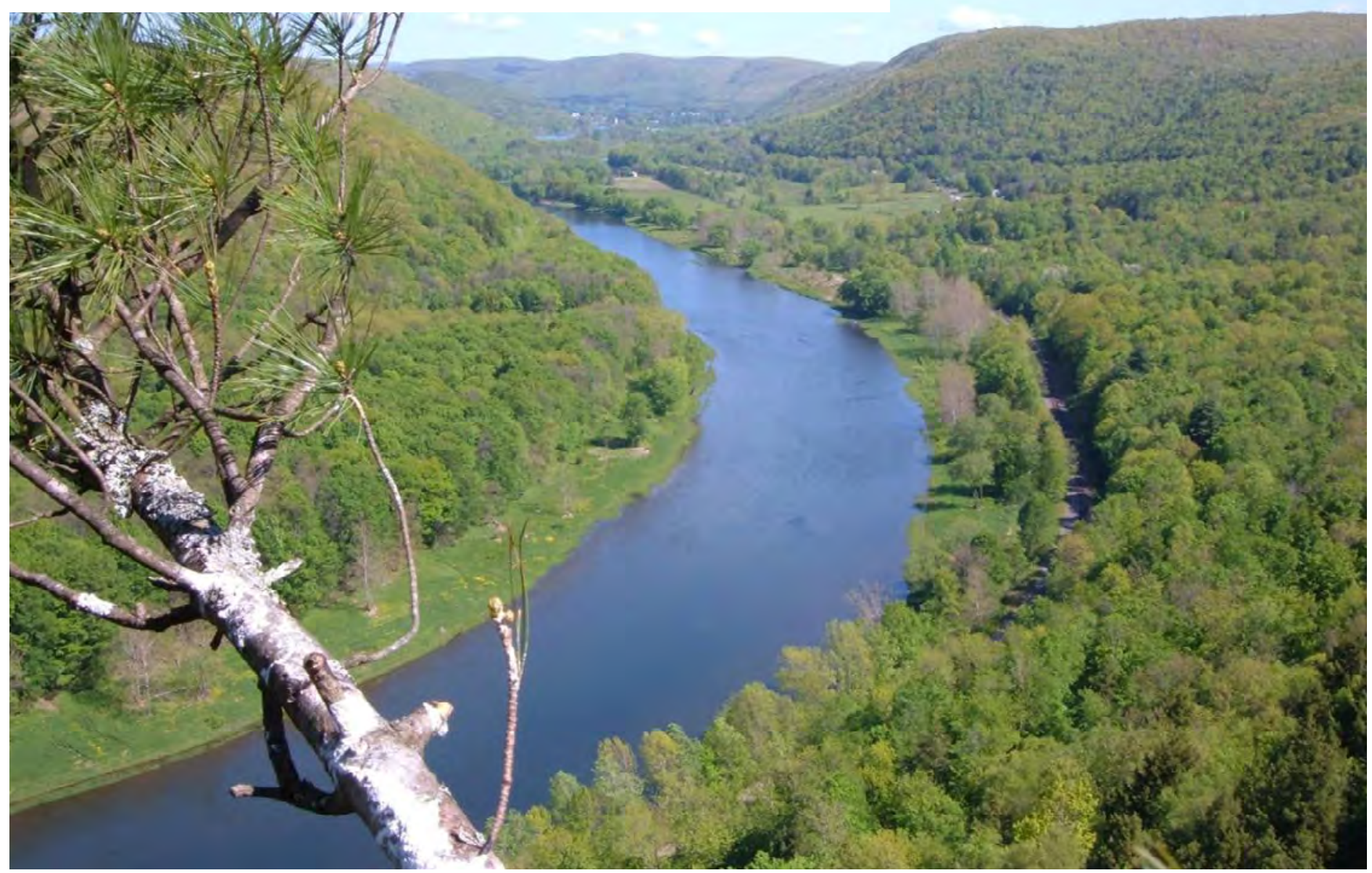

McCoy's Knob, near Hancock, New York. Photograph by Peter Nye, New York State Department of Environmental Conservation.

This newfound awareness of methane contamination of water wells by stray gas migration is based upon studies such as Molofsky and others (2011) who document the widespread natural occurrence of methane in drinking-water wells in Susquehanna County, Pennsylvania. In the same county, Osborn and others (2011) identified elevated methane concentrations in selected drinking-water wells in the vicinity of Marcellus Shale gas-development activities, although pre-development groundwater samples were not available for comparison.
A compilation of dissolved methane concentrations in groundwater for New York State was published by Kappel and Nystrom (2012). Recent work documenting the occurrence and distribution of methane in groundwater was completed in southern Sullivan County, Pennsylvania (Sloto, 2013). Additional work is ongoing with respect to monitoring for stray gases in groundwater (Jackson and others, 2013). These studies and their results indicate the importance of collecting baseline or pre-development data. While such data are being collected in some areas, published data on methane in groundwater are 
sparse in the Upper Delaware River Basin of Pennsylvania, New York, and New Jersey. To manage drinking-water resources in areas of gas-well drilling and hydraulic fracturing in the Upper Delaware River Basin, the natural occurrence of methane in the tri-state aquifers needs to be documented.

The purpose of this report is to present data on dissolved methane concentrations in the groundwater in the Upper Delaware River Basin. The scope is restricted to data for Pennsylvania and New York, no U.S. Geological Survey (USGS) methane analyses are presently available for northwestern New Jersey.

\section{Origin and Occurrence of Methane}

Methane originates from several different sources. "Microbial" methane is produced through microbial fermentation (decomposition of organic matter) or methane produced by carbon dioxide reduction at shallow depths and low temperatures. "Thermogenic" methane is produced from organic matter buried millions of years ago, which has undergone physical and chemical changes at great temperature and pressure. Like methane, other hydrocarbons such as ethane, propane, and butane, or oil also can be produced thermogenically and are typically referred to as "wet gas." In the Upper Delaware River Basin, only methane gas, referred to as "dry gas" is thought to be present. (Marcellus Center for Outreach and Research, 2013)

Methane is a colorless, odorless, tasteless gas that can be flammable or explosive. It can trigger an explosion in enclosed/ confined spaces containing oxygen when an ignition source (an open flame or an electrical spark) is present. Methane can act as an asphyxiate by displacing air in confined spaces and replacing oxygen in animal circulatory systems. Burning methane can produce other toxic gases such as carbon monoxide (Eltschlager and others, 2001).

In groundwater, methane can be dissolved or in a gaseous state. When methane is dissolved, it acts like the carbon dioxide gas used in carbonated beverages, where the gas is held within the fluid under the confining pressure of the sealed container. When the container is opened, pressure is reduced, and some of the gas comes out of solution, which causes bubbling and fizzing in the beverage. In aquifers, methane may be confined by overlying fine-grained deposits or unfractured bedrock. Dissolved methane concentrations in confined aquifers can be much greater than the saturation concentration at atmospheric pressure. As groundwater enters a well at atmospheric pressure, the natural gas can be released from the water, which can cause a column of gas to form above the water surface in the well or be released within a pressure tank, at faucets inside a home, or in structures enclosing the well, where it can become flammable or explosive (Eltschlager and others, 2001).

Dissolved methane reaches saturation in water at 28 milligrams per liter $(\mathrm{mg} / \mathrm{L})$ at atmospheric pressure and becomes flammable in air at about 5 percent by volume (Eltschlager and others, 2001). The Office of Surface Mining recommends that methane concentrations greater than $28 \mathrm{mg} / \mathrm{L}$ in well water be addressed immediately by removing any potential ignition source and venting the gas away from confined spaces (Eltschlager and others, 2001). The Office of Surface Mining also recommends that methane concentrations ranging from 10 to $28 \mathrm{mg} / \mathrm{L}$ in water (or 3 to 5 percent by volume in air) signify an action level where the situation should be closely monitored. Monitoring is recommended because methane concentrations vary as a result of natural fluctuations in atmospheric pressure and groundwater level. In certain cases, a change in methane concentration can be attributed to anthropogenic effects such as increased groundwater pumpage or drilling new water or gas wells that could introduce natural gas from other bedrock strata. If methane concentrations increase in any confined area, the area needs to be vented to prevent methane gas buildup. Concentrations of methane less than $10 \mathrm{mg} / \mathrm{L}$ in water (or 1 to 3 percent by volume in air) are not as great an issue, but the gas needs to be monitored to observe any concentration increases over time (Eltschlager and others, 2001). Homeowners are encouraged to contact their local or State Health Department for further information about measuring and mitigating "action level" methane concentrations (as previously defined) in their water wells or in their homes as these concentrations vary over time.

\section{Sedimentary Bedrock of the Upper Delaware River Basin}

In the Upper Delaware River Basin, most drinking-water wells are completed in sedimentary bedrock formations of Ordovician to Pennsylvanian age (fig. 1). Although most bedrock units are present in New York and Pennsylvania, their names vary between the States. Some of the bedrock units in figure 1 contain strata with high levels of total organic carbon that might be sources of thermogenic methane, but the extent of such strata are not well documented.

\section{Dissolved Methane in Groundwater}

The collection of data on dissolved methane concentration in groundwater by the USGS in Pennsylvania and New York initially began with several groundwater age-dating aquifer studies in the mid-2000s. As part of the age-dating method, dissolved gas samples (nitrogen, argon, carbon dioxide, oxygen, and methane) were collected and analyzed to determine when groundwater recharge occurred. When shale gas development began in Pennsylvania and elsewhere, dissolved gas assessments, using standard USGS methods, were collected in order to characterize dissolved methane concentrations.

The USGS New York Water Science Center, in cooperation with New York State Department of Environmental Conservation, has conducted groundwater-quality monitoring assessments in major river basins in New York (http://ny.water. usgs.gov/projects/305b/). Beginning in 2010, those assessments included sampling for dissolved gases, including methane (Nystrom, 2012). Also, a USGS study conducted in cooperation with the National Park Service, collected groundwater-quality data including concentrations of dissolved methane at six wells in the Upper Delaware River Basin (Eckhardt and Sloto, 2012)

In 2007, dissolved methane data were collected by the USGS Pennsylvania Water Science Center in a groundwater study of Pike County, Pennsylvania (Senior, 2009). In 2012, as part of the Delaware Basin WaterSMART program (http://water. usgs.gov/watercensus/delaware.html), five additional 


\begin{tabular}{|c|c|c|}
\hline PENNSYLVANIA & 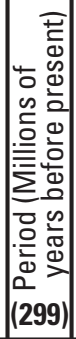 & NEW YORK \\
\hline $\begin{array}{l}\text { Llewellyn Formation } \\
\text { (Sandstone, siltstone, shale, } \\
\text { coal) } \\
\text { Pottsville Formation } \\
\text { (Coal-bearing sandstone, } \\
\text { siltstone, shale) }\end{array}$ & 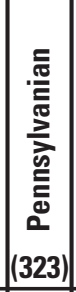 & $\begin{array}{l}\text { Not present in Upper } \\
\text { Delaware Basin }\end{array}$ \\
\hline $\begin{array}{l}\text { Mauch Chunk Formation } \\
\text { (Shale, siltstone, sandstone) } \\
\text { Pocono Formation } \\
\text { (Sandstone, conglomerate) } \\
\text { Spechty Kopf Formation }\end{array}$ & 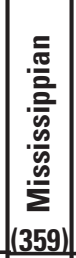 & $\begin{array}{l}\text { Not present in Upper } \\
\text { Delaware Basin }\end{array}$ \\
\hline (Sandstone, siltstone, mudstone) & & \\
\hline $\begin{array}{l}\text { Catskill Formation } \\
\text { (Shale, siltstone, sandstone) } \\
\text { Lock Haven Formation } \\
\text { (Sandstone, siltstone, shale) }\end{array}$ & & $\begin{array}{l}\text { Manorkill through } \\
\text { Slide Mountain Formations } \\
\text { (Sandstone, shale, some } \\
\text { conglomerate) }\end{array}$ \\
\hline $\begin{array}{l}\text { Mahantango Formation } \\
\text { (Shale, limestone, sandstone) }\end{array}$ & & $\begin{array}{l}\text { Hamilton Group } \\
\text { (Shale, sandstone) }\end{array}$ \\
\hline Marcellus Shale & ·疍 & Marcellus Shale \\
\hline $\begin{array}{l}\text { Buttermilk Falls Limestone } \\
\text { Schoharie and Esopus } \\
\text { Formations (Limestone, some } \\
\text { shale, sandstone) } \\
\text { Oriskany and Helderberg Groups } \\
\text { (Sandstone, limestone, shale) }\end{array}$ & $(419)$ & $\begin{array}{l}\text { Onondaga Formation (Limestone) } \\
\text { Esopus and Schoharie Formations } \\
\text { (Sandstone, shale, limestone) } \\
\text { Glenerie Formation (Limestone) } \\
\\
\text { Helderberg Group (Limestone) }\end{array}$ \\
\hline $\begin{array}{l}\text { Decker through Poxono Island } \\
\text { Formations (Thin limestones, } \\
\text { shales) } \\
\text { Bloomsburg Formation } \\
\text { (Shale, siltstone, sandstone) } \\
\text { Shawangunk Formation } \\
\text { (Sandstone, conglomerate) }\end{array}$ & (443) & $\begin{array}{l}\text { Poxono Island through } \\
\text { Manlius Formations } \\
\text { (Limestone, dolostone, shale) } \\
\text { Bloomsburg Formation } \\
\text { (Shale, siltstone, sandstone) } \\
\text { Shawangunk Formation } \\
\text { (Sandstone, conglomerate) }\end{array}$ \\
\hline $\begin{array}{l}\text { Reedsville Formation } \\
\text { (Shale, sandstone) }\end{array}$ & \multirow[b]{3}{*}{ (485) } & $\begin{array}{l}\text { Martinsburg Formation } \\
\text { (Shale, sandstone) }\end{array}$ \\
\hline Utica Shale & & Utica Shale \\
\hline $\begin{array}{l}\text { Trenton and Black River Groups } \\
\text { (Limestone) } \\
\text { Beekmantown Group } \\
\text { (Dolostone, some limestone) }\end{array}$ & & $\begin{array}{l}\text { Black River and Trenton Groups } \\
\text { (Limestone, some shale) } \\
\text { Beekmantown Group } \\
\text { (Dolostone, limestone) }\end{array}$ \\
\hline
\end{tabular}

Figure 1. Comparative bedrock stratigraphic column of the Upper Delaware River Basin, Pennsylvania and New York. Units and lithologies represent surface to near-surface bedrock stratigraphy most likely intersected in bedrock drinking-water wells. Descriptions were supplied by C. Dodge, W. Kochanov, and G. Blackmer of the Pennsylvania Geological Survey, and C. Ver Straeten of the New York State Geological Survey, January, 2013. Geologic Period ages from International Commission on Stratigraphy, 2013 groundwater samples were collected in the Upper Delaware River Basin in New York and Pennsylvania for dissolved-gas analyses; these results are also included in this report. In total, all of these studies provided dissolved methane concentration data for just 25 locations in the Upper Delaware River Basin (fig. 2). The map symbols (fig. 2) show concentration categories for the dissolved methane data in the supplemental data table 1. [Table 1 at http://pubs.usgs.gov/of/2013/1167/table/ Supplemental_data_table1_NYPA_methane .xlsx]

Results of the analyses collected during 2007-12 in the Upper Delaware River Basin indicate that concentrations of methane in groundwater from all but one well ( 96 percent of the wells) were less than the Office of Surface Mining action level of $10 \mathrm{mg} / \mathrm{L}$ (Eltschlager and others, 2001), and a large number of wells ( 52 percent) had no detectable methane (fig. 3). No wells had a dissolved methane concentration between 10 and $28 \mathrm{mg} / \mathrm{L}$, and only one well (of 25) had a measured concentration greater than $28 \mathrm{mg} / \mathrm{L}$ (4 percent). These results are similar to those found in southern Sullivan County, Pennsylvania, by Sloto (2013). Sullivan County is about 75 miles west of the Delaware River Basin and has similar bedrock units - upper Devonian through Pennsylvanianaged bedrock.

Methane was detected in unconsolidated and bedrock aquifers across the basin (fig. 4). About 36 percent of the groundwater samples were from unconsolidated aquifers, and all of those samples had non-detect to low-level methane concentrations (methane concentrations $<1 \mathrm{mg} / \mathrm{L}$ ). Of the samples from bedrock aquifers (64 percent of the groundwater samples tested), 81 percent (13 of 16 samples from bedrock) had dissolved methane concentrations less than $1 \mathrm{mg} / \mathrm{L}$. About 13 percent of the groundwater samples ( 2 of 16 bedrock samples) had concentrations between 1 and $10 \mathrm{mg} / \mathrm{L}$, and about 6 percent ( 1 of 16 bedrock groundwater samples) had a concentration greater than $28 \mathrm{mg} / \mathrm{L}$. In the Upper Delaware River Basin, all of the sampled wells completed in bedrock were in upper to middle Devonian-aged bedrock.

The analysis of dissolved methane in groundwater in the Upper Delaware River Basin (2007-12) is meant to document the natural occurrence of methane in this region but does not indicate whether the methane has a microbial or thermogenic origin. The data describing the occurrence of methane come from a limited dataset collected for general groundwater-quality determinations. Nearly all of the concentrations of dissolved methane are less than the Office of Surface Mining's action levels, but the limited set of available dissolved methane data does not allow for a more precise analysis at this time. The results of this study indicate the need for collection of additional methane data and analysis of groundwater from domestic and public water-supply wells in the tri-state area of the Upper Delaware River Basin.

\section{Acknowledgments}

U. S. Geological Survey personnel from the Pennsylvania Water Science Center (Ronald Sloto and Lisa Senior) and New York Water Science Center (David Eckhardt, Elizabeth Nystrom, and Paul Heisig) collected the dissolved methane data utilized in this report. Also, James Reddy developed the map of the Upper Delaware River Basin. 


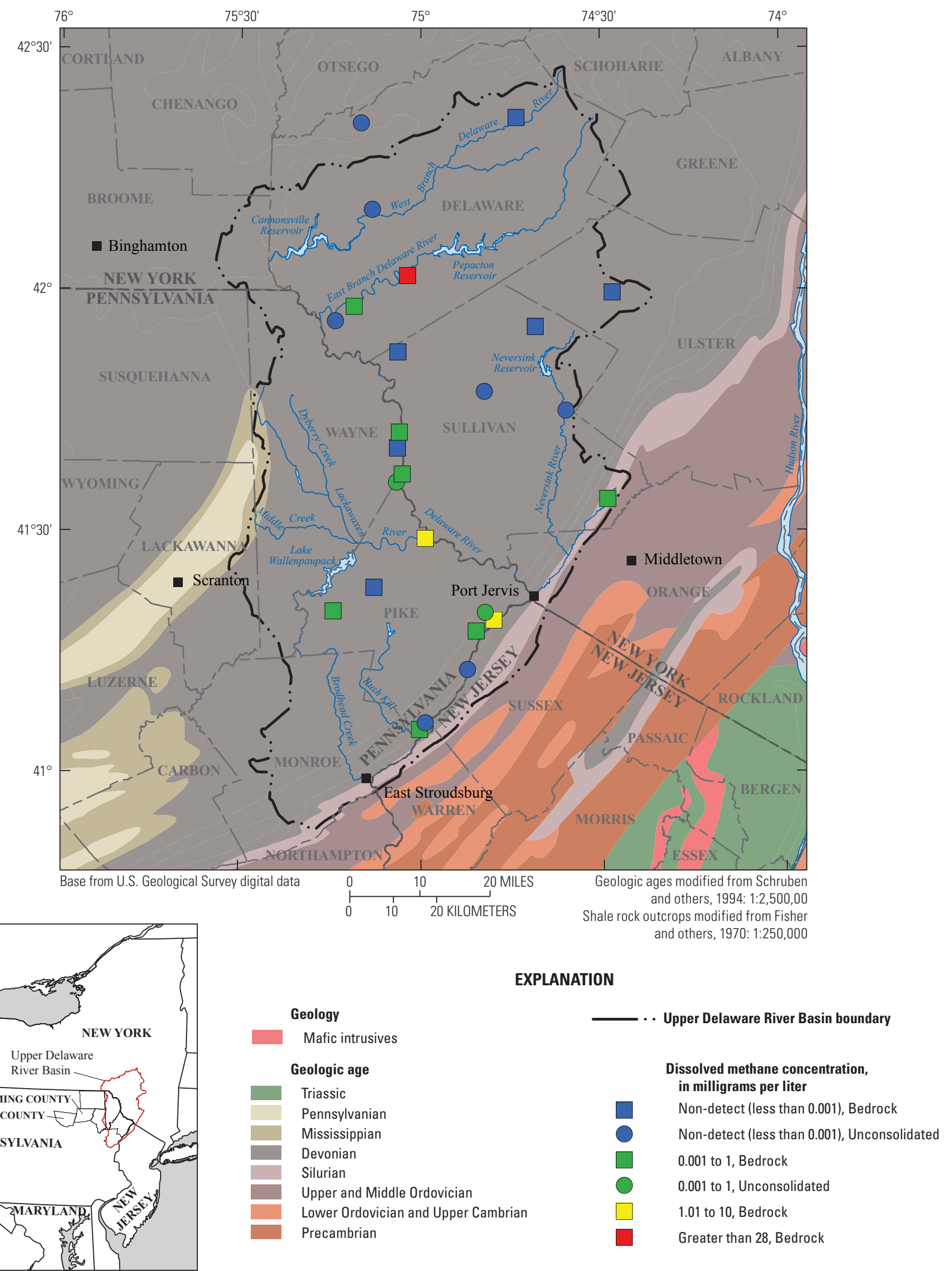

Figure 2. Location of groundwater wells with dissolved methane concentrations, Upper Delaware River Basin, Pennsylvania and New York, 2007-12. 


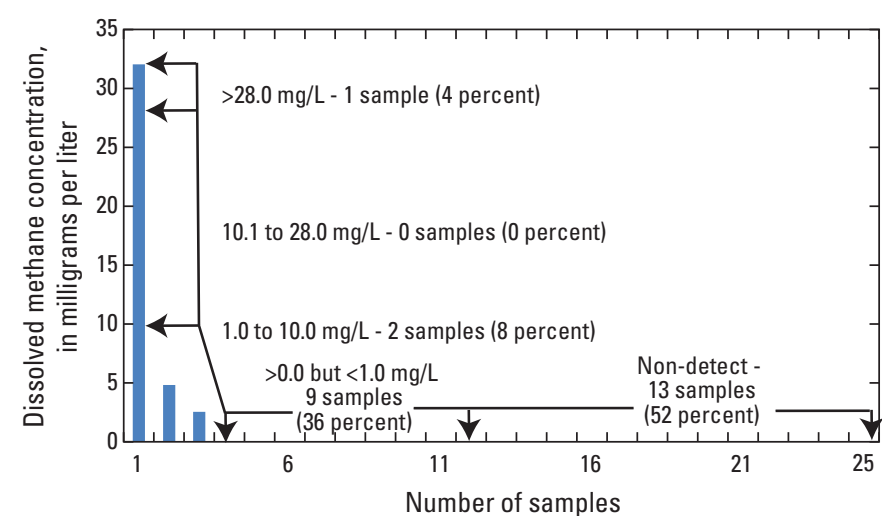

Figure 3. Histogram showing dissolved methane concentrations, by concentration range, in groundwater samples from the Upper Delaware River Basin, Pennsylvania, and New York, 2007-12.

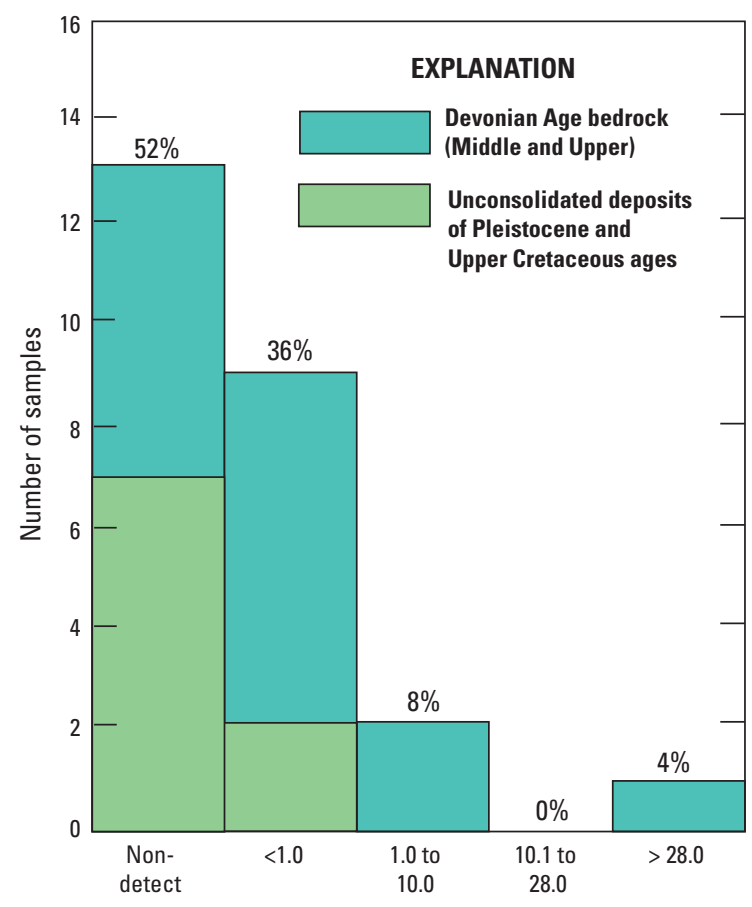

Dissolved methane concentrations, in milligrams per liter

Figure 4. Histogram showing dissolved methane concentrations, by geologic age of aquifer, in groundwater samples from the Upper Delaware River Basin, Pennsylvania, and New York, 2007-12.

\section{References}

Eckhardt, D.A., and Sloto, R.A., 2012, Baseline groundwater quality in national park units within the Marcellus and Utica Shale plays, New York, Pennsylvania, and West Virginia, 2011: U.S. Geological Survey Open-File Report 2012-1150, 20 p. (Also available at http://pubs.usgs.gov/of/2012/1150/.)

Eltschlager, K.K., Hawkins, J.W., Ehler, W.C., and Baldassare, Fred, 2001, Technical measures for the investigation and mitigation of fugitive methane hazards in areas of coal mining: U.S. Department of the Interior, Office of Surface Mining Reclamation and Enforcement, 125 p. (Also available at http://www.techtransfer.osmre.gov/NTTMainSite/Library/ hbmanual/methane/methane.pdf.)
Fisher, D.W., Isachsen, Y.W., and Rickard, L.V., 1970, Geologic map of New York State: Albany, N.Y., New York State Museum Map and Chart Series no. 15, scale 1:250,000.

International Commission on Stratigraphy, 2013, International Chronostratigraphic Chart, accessed June 2013, at http://stratigraphy.org/index.php/ics-chart-timescale.

Jackson, R.B., Vengosh, A., Darrah, T.H., Warner, N.R., Down, A. , Poreda, R.J. , Osborn, S.G. , Zhao, K. , and Karr J.D., 2013, Increased stray gas abundance in a subset of drinking water wells near Marcellus shale gas extraction: Proceedings of the National Academy of Sciences, 2013, DOI: 10.1073/ pnas. 1221635110.

Kappel, W.M, and Nystrom, E.A., 2012, Dissolved methane in New York groundwater: U.S. Geological Survey Open-File Report 2012-1162, 6 p. (Also available at http://pubs.usgs. gov/of/2012/1162.)

Marcellus Center for Outreach and Research, 2013, WetDry Gas, accessed July, 2013, at http://marcellus/psu.edu/ resources/maps.php.

Molofsky, L.J., Connor, J.A., Farhat, S.K., Wylie, A.S., and Wagner, Tom, 2011, Methane in Pennsylvania water wells unrelated to Marcellus shale fracturing: Oil and Gas Journal, v. 109 , no. 49, 12 p. (Also available at http://www.ogj.com/1/ vol-109/issue-49/exploration-development/methane-inpennsylvania-water-full.html.)

Nystrom, E.A., 2012, Groundwater quality in the Delaware and St. Lawrence River Basins, New York, 2010: U.S. Geological Survey Open-File Report 2011-1320, 58 p. (Also available at http://pubs.usgs.gov/of/2011/1320/.)

Osborn, S.G., Vengosh, Avner, Warner, N.R., and Jackson, R.B., 2011, Methane contamination of drinking water accompanying gas-well drilling and hydraulic fracturing: Proceedings of the National Academy of Sciences, 5 p. (Also available at www.pnas.org/cgi/doi/10.1073/ pnas.1100682108.)

Schruben, P.G., Arndt, R.E., Bawiec, W.J., King, P.B., and Beikman, H.M., 1994, Geology of the conterminous United States at 1:2,500,000 scale-A digital representation of the 1974 P.B. King and H.M. Beikman Map: U.S. Geological Survey Digital Data Series DDS-11.

Senior, L.A., 2009, Groundwater-quality assessment, Pike County, Pennsylvania, 2007: U.S. Geological Survey Scientific Investigations Report 2009-5129, 53 p. (Also available at http://pubs.usgs.gov/sir/2009/5129/.)

Sloto, R.A., 2013, Baseline groundwater quality in southern Sullivan County, Pennsylvania, 2012: U.S. Geological Survey Scientific Investigations Report 2013-5085, 34 p. (Also available at http://pubs.usgs.gov/sir/2013/5085/.)

Ver Straeten, C.A., 2007, Basinwide stratigraphic synthesis and sequence stratigraphy, upper Pragian, Emsian and Eifelian stages (Lower to Middle Devonian), Appalachian Basin, in Becker, R.T., and Kirchgasser, W.T., eds, Devonian Events and Correlations: The Geological Society of London, Special Publication 278, p. 39-81. 


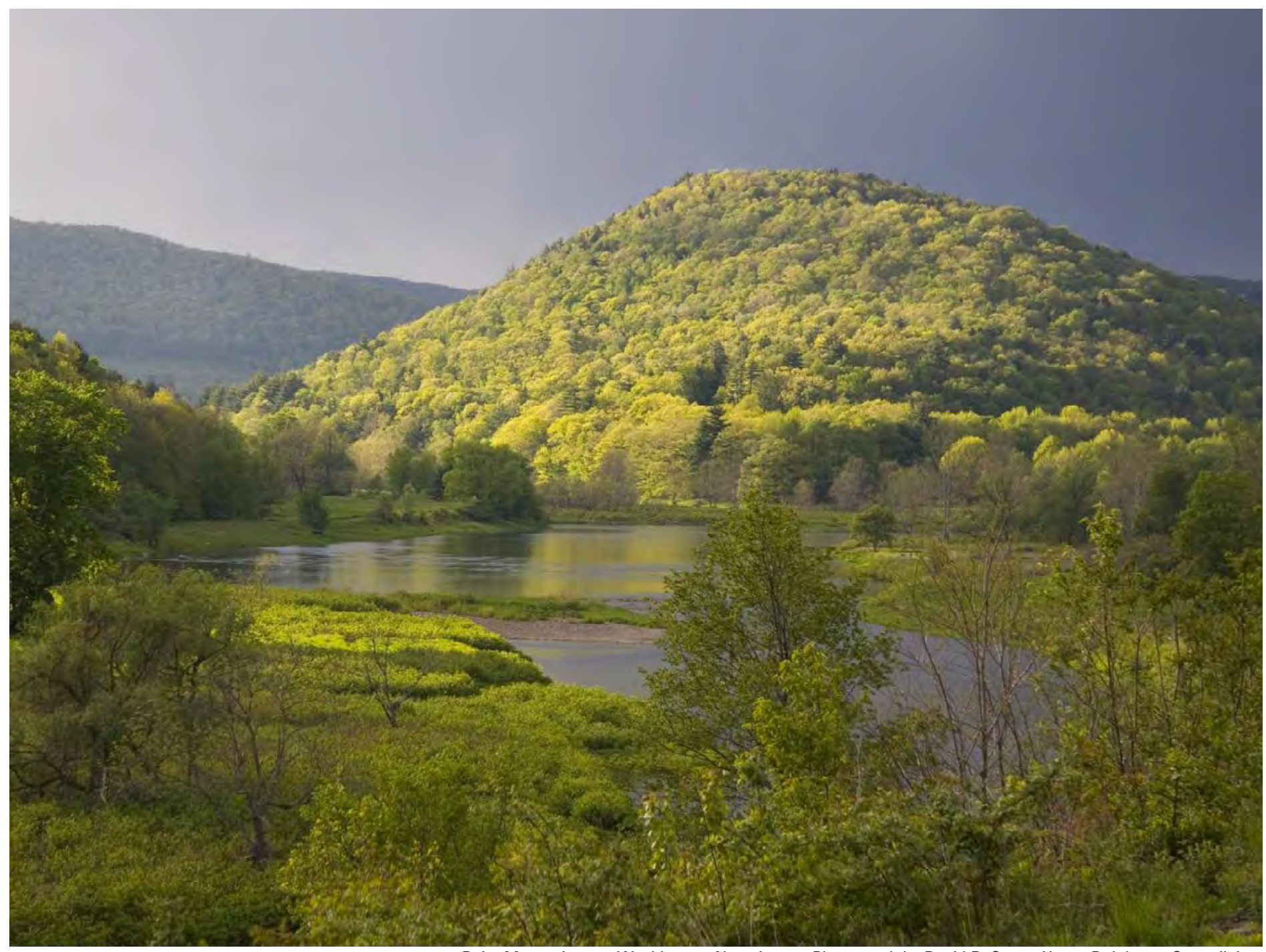

Point Mountain near Washington, New Jersey. Photograph by David B. Soete, Upper Delalware Council, Inc.

By William M. Kappel

\section{For additional information write to:}

New York Water Science Center U.S. Geological Survey 30 Brown Road

Ithaca, NY 14850

or visit our Web site at:

http://ny.water.usgs.gov
For more information on the USGS - the Federal source for science about the Earth, its natural and living resources, natural hazards, and the environment: World Wide Web: http://www.usgs.gov Telephone: 1-888-ASK-USGS
Any use of trade, product, or firm names is for descriptive purposes only and does not imply endorsement by the U.S. Government 